\title{
Rīgas kolēǵu vēstules Paulam Stradiñam uz ASV un Lielbritāniju 1925. gadā: H. Budulis, J. Alksnis, P. Mucenieks, E. Paukulis (no P. Stradiņa personiskā arhīva)
}

\author{
Jānis Stradiņ̌̌
}

1925. gadā Pauls Stradiņš un Jēkabs Prīmanis konkursa kārtībā ieguva Rokfellera stipendiju, lai varētu papildināties zinātnē un gatavoties tālākai akadēmiskai karjerai dzimtenē - Latvijas Universitātē. Abi viṇi bija pirmie Rokfellera stipendiāti no Latvijas ne tikai medicīnā, bet zinātnē vispār, un ar to sākās Latvijas un ASV zinātniskā sadarbība (oficiāli diplomātiski sakari starp abām valstīm tikai nule bija nodibināti). Šo stipendiju piešķiršsanu veicināja ASV padomnieki tieši medicīnas jomā, kas palīdzēja Latvijai humānajā jomā un militārmedicīnā (vēstulēs minētie pulkvedis Hjūms un Reins). No 1925. gada janvāra P. Stradiņš papildinājās brālu Mejo ķirurğiskajā klīnikā, kas tolaik skaitījās labākā pasaulē. Taču 1925. gada otrajā pusē viņš bija spiests pārcelties uz Londonu, daḷeji ǵimenes apstākḷu dēl, jo dzīvesbiedre N̦ina Stradina kategoriski atsacijās dzīvot pie vīramātes un vīramāsām, piedraudot pat atgriezties Petrogradā (par to saglabājusies dramatiska, vēl nepublicēta sarakste, ko N̦. Stradiṇa nodeva man pirms aiziešanas mūžìbā). Tādēl atlikusī komandējuma daḷa pavadìta Londonas k̦irurǵiskajās klīnikās un laboratorijās, kas nebija ne tuvu tik labi nostādītas, taču ḷāva gūt ieskatu britu medicīnā un vēlāk ḷoti tuvināja P. Stradiṇu angḷ kultūrai (viņš piedalījās prof. N. Maltas vadītās britu organizācijas "All Peoples Association" (APA) Latvijas nodaļas izveidošanā un šĩs organizācijas prezidenta sera Evelīna Vrenča (Wrench) sagaidīšanā un pieņemšanā Rīgā 1933. gadā).

Gatavojot atmiņu un dokumentu grāmatu par Paulu Stradiṇu 1960. gadā, man izdevās sameklēt daudz materiālu par viṇa uzturēšanos ASV (dienasgrāmatu "Amerikas burtnīcas") un Hruščova atkušṇa apstākḷlos publicēt to, gan ar lielām grūtībām, grāmatā "Pauls Stradiņš dzīvē un darbā", Rīgā, 1961). Krievu tulkojumā, paplašinot materiālu ar izrakstiem no Paula Stradiņa vēstulēm N̦. Stradiṇai (vēstules krievu valodā), taču ar daudziem cenzūras-redakcijas noteiktiem izlaidumiem 
(un pat labojumiem!), dokumentāls vēstījums publicēts P. Stradiṇa rakstu izlasē 1965. gadā.

Jau tolaik tika sagatavotas publicēšanai arī kolēgu ķirurgu Jēkaba Alkšņa, Pāvila Mucenieka un LU Medicīnas fakultātes dekāna Hermaņa Buduḷa vēstules P. Stradiṇam uz Ameriku, taču grāmatas redig̣ēšanas laikā notika "Pauersa incidents" ar ASV izlūklidmašīnas notriekšanu virs PSRS teritorijas, kas izjauca D. Eizenhauera un N̦. Hruščova tikšanos. Pieauga politiskā spriedze starp abām valstīm un ar A. Pelšes nākšanu LKP CK pirmā sekretāra amatā beidzās relatīvi iecietīgā attieksme pret latviešu trimdu, tādēl arī šis vēstules lika izṇemt no jau sagatavotās grāmatas manuskripta. Krievu tulkojumā tās tomēr dalẹji (ar piespiedu īsinājumiem, kas skāra politiskās norises, piemēram, valdības locekḷu raksturojumu neatkarīgajā Latvijā 1925. gadā) publicētas jau minētajā P. Stradiṇa rakstu izlasē ("buržuāzisko" darbinieku un emigrantu sacerējumu publicēšana tolaik, Pelšes laikā, vispār bija bezprecedenta gadijjums!).

Šodien, kad tik sekmīgi izvēršas Latvijas un ASV kontakti medicīnas jomā un pat ieviests bezvīzu režīms, šķiet mērḳtiecīgi publicēt šīs agrīnās liecības par akadēmiskās medicinas zinātnes sākumiem Latvijas Universitātē un ārzemju kontaktu meklējumiem neatkarīgajā Latvijā, arī ASV. J. Alkšņa P. Mucenieka, H. Buduḷa un E. Paukul̦a vēstules sniedz labu ieskatu LU Medicīnas fakultātes un Rīgas slimnīcu dzìvē. Brīvā formā apcerēti tādi svarīgi notikumi kā prof. J. Jankovska aiziešana mūžỉbā, G. Bakmaņa atgriešanās Zviedrijā, 1. Latvijas ārstu kongress, E. Putniņa atstādināšana no 1. pilsētas slimnīcas vadības, pirmie mēgeinājumi reanimēt Rīgas pilsētas 2. slimnīcu (tagad P. Stradiṇa Klīniskā universitātes slimnīca) kā Medicīnas fakultātes klīnisko bāzi, P. Mucenieka un J. Miḳelsona disertāciju aizstāvēšana u. c. Vēstulēs pieminēti pazīstami ārsti kịurgi Anna Bormane (vēlāk - Latvijā pirmā sieviete medicīnas zinātņu doktore), Aleksandrs Mežciems, Pāvils Mucenieks, kas tolaik strādāja J. Alkšņa klīnikā, tāpat avantūristiskais profesors J. Dzirne, pret kura piesaistǐšanu Medicīnas fakultātei īpaši asi vērsās Alksnis, bet kuru protežēja J. Ruberts, R. Krimbergs un P. Sniķers. Tā kā P. Stradin̦š 1924.-1927. g. skaitījās Latvijas armijas medicīnas dienestā kā ārsts leitnants, viņam bija jārisina arī ar šo jomu saistīti jautājumi un tādēl jākontaktējas ar medicīnas generāli Pēteri Sniķeri (kas bija J. Alkšņa "pretinieks"). P. Sniķera uzdevumā saraksti veica viṇa palīgs kara sanitārās pārvaldes jurists Viktors Saulītis (starp citu, korporācijas "Fraternitas Metropolitana" atjaunotājs un pirmais seniors Rīgā), kura vēstuli arī publicējam. Pieminēta P. Stradiña meitas Irēnas piedzimšana, kuras krusttēvs bija P. Mucenieks.

Vēstules apliecina kolēǵu cieņu un labvēlību jaunajam Paulam Stradiņam, LU Medicīnas fakultātes vēlmi gatavot viṇu katedras vadìtāja amatam. Tādējādi viṇa potenciālās spējas jau agri tika ievērotas un novērtētas dzimtenē, un P. Stradiņš nebija spiests palikt ārzemēs, kaut šādi piedāvājumi vairākkārt bijuši. Bija arī liels patriotisms un vēlēšanās veidot akadēmisku, modernu Eiropas līmeṇa medicīnu Latvijā, balstoties uz labāko ārzemju pieredzi. Tas izskan gan vecākās paaudzes 
kolēǵu, gan jaunāka gadagājuma mediḳu viedoklī, un tieši tādēl neatkarīgās Latvijas 20 gados paguva tik daudz paveikt, arī medicīnā. Savukārt Rokfellera fonds kā institūcija l̦oti lielā mērā radīja reālas iespējas jaunajiem Latvijas zinātniekiem papildināties labākajos ārzemju centros (vēlāk arī E. Dārziņam, K. Dolietim, P. Vegeram u. c. medicīnā, L. Āboliṇam - biologijāa, B. Bružam - fizikā, A. Spekkem - filologijā, u. c.).

\section{Hermanis Buduls - Paulam Stradinam}

\section{IX 1925 Rīgā}

\section{Ļoti godāts kolēǵa kgs!}

Sirsnīgi pateicos, ka Jūs veltījat man tik daudz uzmanības un mani informējat par Jūsu studiju gaitu. Visi fakultātes locekḷi un viṇu starpā ne mazāka mērā arī es, ar lielu interesi saṇem ziņas par Jūsu sekmēm un ir gatavi katrā brīdỉ atbalstìt Jùsu vēlēšanās un vajadzības. 14. sept. fakultātes padomes sēdē vienbalsīgi nolēma, ka Jums pieškirams pagarinājums attiecībā uz atvaḷinājumu vismaz uz pusgadu, bet ja būs vajadzīgs, arī vēl uz ilgāku laiku. Mēs jau pusgadu varam kaut kā paknapināties, apzinoties, ka katrs mācības spēks, kuram ir dziḷa un vispusīga medicīniska izglīīiba, mums ir ḷoti dārgs un ka Jums otrreiz diezin vai vairs būs izdevība tik plaši un dažādi iepazīties ar dažādām problēmām medicīnā kā šoreiz. Man personīgi ir prieks, ka Jūs par nervu sistēmu tik lielā mērā interesējieties. Pēdējā vēstulē Jūs speciāli miniet jautājumu par muskuḷu atrofiju pie locītavu iekaisumiem vai [..]?

Šis ir l̦oti interesants jautājums un līdz šim tiešām maz izpētīts un maz uz eksperimentu pamata nervu sistēmas fiziologiju dibināts, kaut gan faktiski katrs te novērojis dažkārt ḷoti acīs krītošas parādības.

Mūsu universitāte jau vēl ir jauna un neizveidota, tāpat arī medicīnas fakultāte. Studentu apmācībā mēs pieturamies vēl pie vecās sistēmas. L̦oti var būt, ka vienā otrā vietā varētu ienest svaigāku garu un pašu mācības gaitu padarìt studentiem vieglāku, bet patiesās zināšanas par nepieciešamām lietām vispusīgākas, dzīvākas un dziḷākas. Šai laukā Jums būs pa šiem gadiem iespējams sakrāt plašus novērojumus, un es ceru, ka nākotnē Jūs mums vienā otrā lietā varēsiet nākt talkā ar lietderīgiem padomiem. Sevišķi angl̦u tauta ir praktiska un savos centienos pamatīga tauta, un to no viņiem mums sevišksi daudz vajadzētu mācīties. Par nožēlošanu līdz šim mūsu garīgais kontakts ar šo lielo tautu ir palicis l̦oti paviršs. Bet cerēsim, ka nākotnē tas būs pavisam citādi, un še Jums kā ārstam būs sevišḳi liels nopelns, ja Jūs varēsit pa daḷai robu aizpildīt, kurā līdz šim tik lielā mērā sajūtams šai lietā.

Tātad turpiniet savas studijas bez kādām raizēm, nedomājot par to, kā mēs mājās ar darbiem iekārtosimies. Tas pats sakāms arī attiecībā uz kolēgi Prīmaņa kungu. Viṇa nākošais šefs prof. Starkovs gan vēl nav atbraucis, bet kad viņš iera- 
dīsies Latvijā, viṇu pierunāsim kādu pusgadu intensīvāk pastrādāt, nekā tas būtu varbūt vajadzīgs, ja Dr. Prīmaņa kgs būtu jau atbraucis.

Novēlu Jums visu labu un arī turpmākā darbā daudz sekmes!

\section{E. Paukuls - Paulam Stradingam}

\section{Rīgas jūrmalā 11. VI. 1925}

L,oti god. Kolēga kungs!

Man ḷoti nepatīkami, ka uz Jūsu laipnām u[n] garām vēstulēm Jums bija no manis tik ilgi jāgaida atbilde. Bet šopavasar bija mums fakultātē tik daudz dažādu ārkārtēju darbu u[n] tā kā tie pa lielākai daḷai guḷas uz manis kā uz "skrīveri", tad pilnīgi negribot paliku Jums atbildi parādā. L̦oti patīkamas mums ir ziņas no Jums un Prīmaṇa, ka esiet tik l̦oti apmierināti ar savu darbu u[n] Jums ir iespēja nākt pat personīgās attiecībās ar tagadējiem šefiem. Droši ceram, ka tas cels mūsu jaunās universitātes prestižu pie amerikāņiem $u[n]$ ienesīs mums uz priekšu saistoši noteiktu labvēlību no Rokfellera fonda puses. Spriežot pēc Jūsu vēstulēm u[n] tām visām iespējamībā, ko Jūs tur visu tik bagātīgā apmērā varat strādāt $\mathrm{u}[\mathrm{n}]$ katru dienu redzēt ciešāā kontaktā gar acìm slīdot, mums veciem te atliek gandrīz tik vienīgi Jūs apskaust. Šinīs dienās taisāmies rakstīt Dr. Eversolam u[n] ievadìt sarunas par jaunu stipendiātu komandējumiem, tad zināms nāks par labu mums labās atsauksmes par pirmiem stipendiātiem, kādas bez šaubām būs Eversols jau ievācis. - Tagad nu pastāstǐšu Jums, kā mums pa Rīgu gājis. Svarīgākais tas, ka 2 mūsu asistenti nopromovēja: Mucenieks u[n] Miķelsons. Abiem bija paprāvi darbi ("par žultsvadu plastiku", "par dažām tuberkulozes serodiagnostikas metodēm"). Pie abām disertācijām biju recenzents $u[n]$ arī ofic. oponents. Un tad bija vēl 2 goda promocijas ceremonijas: Dr. Kasparsona u[n] Bakmaṇa. Ka jau laikam zināsiet, prof. Bakmani aicināja u[n] viņš aizgāja uz Stokholmu par profesoru, pirms nedēlas jau pat izvadījām ceḷā. Aiziešanas gadỉjumā tad nu pieškīrām viņam Dr. medhonor. causa un valdība pieškīra viņam pat Triju Zvaigžṇu ordeni, kā pirmajam no augstskolas profesoriem. Mūsu izredzes uz II pils. slimnīcu liekas mazdrusciṇ pavirzījušās uz priekšu. Ministru kabinets ir nolēmis dot pilsētai 40 miljonu klīniku iekārtošanai med. Fakultātes vajadzībām. Zem kādiem trakiem nosacijumiem tas notiks, to vēl nezinām. Pilsēta gribot paturēt saimniecību pati savās rokās $\mathrm{u}[\mathrm{n}]$ arī visā pārējā pārvaldē būt par galveno noteicēju, u[n] tad jau te būtu atkal tādas pat nesaprašanās $u[n]$ pastāvīgas rīvēšanās, kā tagad I pils. slimnīcā. Un kur daudz kungu un noteicēju, tur jau parasti vairāk plēšanās, nekā darbu darītāju. 
Tad vēl Jums interesēs, ka ḳirurğ. patologiiju nākošā māc. gadā uzdosim pagaidām atkal prof. Alksnim. Operatīvo ķirurgíju arī uzdevām vēl uz gadu līdzšinējam priv. - doc. Trofimovam.

Ar daudz sveicieniem $\mathrm{u}[\mathrm{n}]$

visa laba vēlējumiem

Jūsu E. Paukuls

L,oti god. Kolēga!

Pateicos par vēstuli. Steidzos Jums ar Jūsu kundzi paziņot, ka aizvakardienas sēdē mēs nolēmām piešḳirt Jums vēl 1 gadu komandējuma, kā Jūs to vēlējāties. Lūdzu paziņot mums, kas u[n] kā būtu šinī ziṇā jādara attiecībā uz Rokfellera fonda valdi: kam u[n] kādā veidā iesniegt lūgumu no fakultātes. Vislabāk Jūs paši mums varētu angḷu valodā atsūtīt iesniegšanai vajadzīgos rakstus. Jūsu agrākajam šefam jau sen nosūtijām pateicības rakstu - kādu Jūs vēlējāties.

Visu labu

Jūsu E. Paukuls

\section{Jēkabs Alksnis - profesoram Paulam Stradiņam}

\section{Rīga, 3/III 1925}

Ļoti cien. Stradiņa kgs!

Es saṇēmu Jūsu abas vēstules un par tām l̦oti pateicos. Diemžēl nepaspēju Jums tik àtri atbildēt, kā es būtu vēēejies. Kā Jūs zināt, darba man pietiek.

Ar lielu prieku lasišu Jūsu ziņojumus par novērojumiem Amerikā un pēc iespējas ievietošu arī mūsu žurnālā. Lai Dievs Jums piepalīdz ierīkoties un iekārtoties, jo labi zinu, ka šis komandējums Jūsu dzīvē ir liels lūzums, savienots ar l̦oti lielām grūtibām. Fakultātē un universitātes padomē ziṇoja, ka aț̣auts Jums un Prīmanim saṇemt arī šejienes algu. Bormaṇa jkdze no katra atlīdzinājuma atsakās un mēs ar viṇu šo gadu izsitīsimies cauri, atstādami Jūsu vietu Jums, lai vēlāku nebūtu nekādu sarežg̀ijumu. Tas zināms arī Jūsu kundzei, un, ja es nemaldos, viṇa ar Jūsu pilnvaru var saṇemt Jūsu algas tiesu. Ja tur kaut kas neietu kārtībā, lai viņa griežas pie manis.

Mums iet pa vecam. Putniņa lieta pamazām apklust. Dr. Meijs dabūja viṇa vietā būt pie miertiesneša, jo tā nabadzìte sieviṇa, kuru viņš nav uzṇēmis slimnīcā, viṇu ir sūdzējuse. Bet miertiesnesis nav nekādu spriedumu taisījis un nodevis visu to lietu prokuroram. Tā vēl var atkal uzpeldēt visa šì neglìtā lieta. - Atkal iekustināta lieta par otro pilsētas slimnīcu. Varbūt, ka šoreiz kaut kas iznāks, jo arī pilsētai vajadzīga otra slimnīca. Slimokases arī ieinteresētas. Bet naudas valstij ir 
liels trūkums, jo mūsu kokus mīkstās ziemas dēl nedabūja eksportēt. Tomēr man liekas, ka valsts un pilsēta panāks vienošanos, jo abām šoreiz slimnīca nepieciešama. Varbūt, ka Jūs varēsiet savu darbību Latvijā turpināt jau jaunā slimnīcā, t. i., îstenā klīnikā.

Mums katru nedēḷ 1-2 ulcera ventriculi. Atbrauca no Vīnes mūsu rentgenologs Dr. Romans, kas tur vienu gadu strādāja pie Holcknechta un citur. No tā laika mūsu diagnozes arī vairs tā neklibo, jo viņš šo lietu pārzina un uz viņu var palaisties. Pagājušā nedēḷā es zaudēju no šìs operācijas pirmo slimnieku: bija jau priekš operācijas bāls, un līdz pat iestāšanai klīnikā vienmēr dzēris. Nomira ḷoti negaidìti 3ā dienā pēc operācijas ar kaut kādām intoksikācijas pazìmēm, kuras man l̦oti atgādināja delirium tremens. Sekcija arī noskaidroja, ka šuves un anastomoze pilnā kārtībā, peritonìta nav, plaušās nekā; bet bija uzkrītošs smadzeṇu edēms un vēnas pārpildītas. Bormaṇa jkdze strādā nekas, tikai viņa drusku inerta un arī stipri bailīga. Mucenieks palicis atklātāks un man šḳiet, ka arī attiecības ar Mežciemu viņiem uzlabojas. Es izskatīju un izkoriǵēju (valodas ziṇā) viņa disertāciju. Jārecenzē man, Paukulim un Jankovskim līdz 30./III 1925. Tā tad laikam mēs vēl šo pusgadu promovēsim.

"Lat. Ārstu žurn." paliek arī turpmāk manā vadīšanā. Iznāks turpmāk 6 burtnìcas gadā.

Es Jums piesūtî̌u no brīveksemplāriem, kurus es kā redaktors saṇemu. Mēs gaidīsim arī no Jums referātus un oriǵināldarbus. Honorārus es nodošu Jūsu kundzei. Jā - Jūsu kundzei varbūt uzkrìt, ka es viṇu neesmu izsaucis lekcijā. Rakstāt viṇai, ka es to negribēju viņas stāvoklì apgrūtināt un semestri es jau tā kā tā ierakstišu.

Es nezinu, vai Jums zināms, ka mūsu rektors Ruberts saslima ar mazu apoplektisku insultu - laikam trombozi. Viņš ātri atveseḷojas, kaut gan vēl lekcijas nelasa, bet jau staigā. Tas mūsu sarežğìtā fakultātes un universitātes dzìvē bija liels sitiens un liels trūkums. Ja viņš dzīvos kārtīgi un ieturēs diētu, viṇš būs vēl daudzus gadus darba spējīgs. - Adelheimu promovēja par profesoru. Pelnījis viņš to bija.

Es Jūs l̦oti lūgtu, Stradiña kgs, piegriezt lielu vērïbu laboratorijai (bakter. un patoloğ.), jo tās mums tiešām trūkst. Manos gados jau tehniski grūti tādās lietās papildināties, kaut gan es patologiskā anatomijā varbūt daudz vairāk zinu, nekā dažs labs no maniem kolēgiem fakultātē, kas brūḳe "lielu muti". Tomēr tas ir viss pašmācība, un ar to nepietiek. Jums piekritīs uzdevums nodibināt Latvijas Universitātē laboratorijas darbus ķirurǵijā. Ķirurğisko techniku mācās visu mūžu un, pārvaldot aseptiku un anatomiju, vienmēr var strādāt un iestrādāties. Ar laboratoriju tas nav tik vienkārši.

Ka Amerikā daudz strumu, to man sacīja kāds amerikānietis Leipcigā. Varbūt Jūs varētu kādā darbā vinas raksturot? Interesanti, kādas Maijo indikācijas ulcus ventriculi terapijā un kā viņš rỉkojas pie žults ceḷu slimībām: indikācijas cholecistektomijai, choledocha drenāžai, cholecistostomijai un choledochoduo- 
denostomijai (pie beidzamās operācijas - ciktāl tā lietota choledocha drenēšanās vietā)?

Par Rokfellera fonda latviešu stipendiātu skaita pavairošanu es domāšu un būtu jāatrod vispirms kandidāti, iekams to lietu iekustina. Acumirklī tiešām nezinātu, par kādiem kandidātiem domāt. Ķirurgus jau vairāk nesūtīs. Es parunāšu ar Rubertu un ar saviem klīnikas kolēgiem.

Jūsu darba novilkumus (D. Z. f. Chir.) nosūtīju Jūsu kundzei un dažus paturēju sev, ko izdalìt vienam otram fakultātes loceklim.

Novēlu Jums veselību un sekmes darbā! Ne katrs Jūsu vietā būtu bijis iekustināms uz komandējumu. Tas ir tomēr liels darbs, kuru Jūs esat uzṇēmušies. Par katru Jūsu soli uz priekšu es priecāšos kā par sava paša soli.

Kolēgii lūdz sveicināt, tāpat arī mana sieva.

Jūsu Alksnis

Seasons greetings with all kind thoughts and best wishes for Christmas and the New Year.

Sincere good wishes for a very Merry Christmas and a happy New Year

\section{J. Alksnis - P. Stradinam}

\section{Rīga, 99./V 1925}

\section{Mịlo kolēgii!}

Atbildu uz Jūsu vēstuli no 31./III. Domāju, ka Jūs pareizi darāt, koncentrēdami savu darbību uz laboratoriju. Jums taču paredzēta vispārīgā kirurğija ar patolog̣isko fiziolog̣iju un eksperimentālo daļu pie mūsu augstskolas, tur divu domu nav. Man škikiet, ka Jums arī fakultātē nodrošināta majoritāte. Operatīvo tehniku un klīniku der noskatīties, bet cilvēks, kas pārvalda anatomiju, aseptiku un ikdieniškos tehniskos paṇēmienus, var vienmēr vēlāk dzīvē pats iestrādāties. Un ka Jūs to spējat, par to man šaubu nav. Bet kaut ko jaunu radìt, pārbaudìt - bez laboratorijas nevar.

Dzīve rit pa vecam. Semestra beigās, kā arvienu, esmu drusku noguris. 14. maijā Mucenieks aizstāvēs savu disertāciju. Tā ir čakli strādāta, viṇš sasniedzis arī rezultātus ar praktisku nozīmi. Iekārta un ārējais ietērpums varētu būt labāki. Kaut gan es viņu darīju uzmanīgu, lai viņš tur tik daudz neiepin allo-, hetero-, homoplastikas jautājumus, jo patiesībā šie termini pēc būtības lietai nemaz nepieder un lieta ir vairāk protezēšana ar gumijas cauruli, nekā alloplastika, un peritonizēšana un omentizācija, nekā homo- un autoplastika, tomēr viņš mani neklausijja, un paredzu, ka viņam būs pagrūti sevi aizstāvēties šai lietā (Paukulis šai lietā oponēs, es jau nekā neaizskaršu). Viṇš nedeva darbam 


\section{J. Stradiň̌}

arī labu un pārskatāmu noslēgumu, kaut gan es arī uz to aizrādīju, un man jau bija fakultātes sēdē jāiztur viena ataka no Jankovska, kura atkristu, ja tāds kategorisks noslēgums darbam būtu, bet tai vietā nebūtu tāds kautrīgs jautājums, cik darbam praktiskas vērtības un tādas pašas kautrīgas atbildes uz to, no kam lasītājs, kas visu darbu neizlasa, var nākt pie slēdziena, ka autors pats šaubās par saviem rezultātiem un darba vērtību. Darbam tiešām ir lielāka vērtība, nekā Mucenieks to izcēlis. Bet viņš nu diemžēl ir tāds pastūrgalvīgs un dažreiz taisni acimredzamas lietas negrib saprast. Vispirms Jankovskis esot nosolijies vinam stipri uzbrukt, un arī Putniņš gribot oponēt apendicīta jautājumā (viņš uzstādījis vienu tēzi par apendicītu pie sievietēm). Tātad man drusku rūpes, kā Mucenieks sevi aizstāvēsies, kaut gan tie uzbrucēji jau nu nav nekādi lielie. Labais ir tas, ka es kā šefs oponēšu beidzamais. Ar tiem apendicītiem tā lieta vēl tāda, ka viņš pārāk daudz sāka likt ar "apendicītiem" savā nodą̧ā un to starpā bija zināms procents arī iedomātu apendicìtu un patiesībā ginekoloǵisku gadijumu, par ko jau vienreiz Putniņš insinuēja fakultātes sēdē (Mucenieks arī pret viṇu ir liecinājis). Un pie tam vēl viñam šo pusgadu 4 slimnieces - gandrīz viena pēc otras - saslima pēc vienkāršas apendicìta operācijas (intervalā) ar peritonītiem un divas pat nomira, bet divas vēl tagad struto. Kas tur bija par vainu, tiešām nezinu, bet baiļojos, ka pārāk steidzīga un pārdroša operēšana, pie l̦oti maza ādas grieziena pietiekoši neapšujot apendicǐša galu. Vienai bija aknu abscess, infiltrāti vēderā, vēlāk pleirīti. Vienai abscess perforēja uz mīzalpūsli. Es tādas lietas savā mūžā nebiju pieredzējis. Pēc tam mēs ar kolẹgi nopietni tās lietas pārrunājām un tagad viņš operē ar lielāku izlasi. - Mịlo kolēgí, lūdzu nepārprast, ka es par Mucenieku sūdzētos, bet es jau nu Jums tā uzticos, ka domāju - varu ar Jums arī klīnikas sirdslietas pārrunāt. Mūsu attiecības ar Mucenieku beidzamā laikā, kur es viṇam esmu visādi izpalīdzējis - esmu viṇa disertāciju ne vien izstudējis, bet arī valodas un citā ziņā izkoriǵéjis no "A" līdz "Z", ir labākas, nekā agrāk. Viṇš bija drusku iedomīgs palicis, tos apendicîtus operēdams, sevišḳi kad bija dzirdējis glaimus par apendicîtu ātru operēšanu, bet tagad atkal daudz nosvērtāks un mierīgāks. Viṇš ir tāda daba, kas ātri no kādas iedomas aizraujas un tad paliek pat nekritisks savā darbībā. Bet vispārim mums klīnikā iet labi, kaut gan es sāpīgi sajūtu Jūsu trūkumu, jo Bormaņa jkdze pūlas un cenšas, bet tomēr viña Jūsu darbu visā pilnībā nest nevar. Asistentu savstarpējās attiecības, man škịet, tagad pat labākas, nekā priekš dažiem mēnešiem. Asistentu zinātniskie vakari gan klibo, jo trūkst Jūsu entuziasma un enerğiskās rokas. Miķelsons savu disertāciju (par tbc serodiagnozi etc.) aizstāvēs 22./V. Šulcs pazaudēja vienu nieri (Jankovska asistents), bija pionefroze. Mežciemam uzdeva tematu: pārbaudìt ascendējošās infekcijas briesmas pēc choledochoduodenostomijām un vispārim pēc papilla Vateri destrukcijas. Varbūt to vasaru nobeigsim.

$\mathrm{Nu}$ es Jums gan sarakstīju par klīnikas internām lietām vairāk, nekā tas man varbūt nācās, bet zinu, ka Jūs manu atklātību nelietīgi nevalkāsiet. Un pie tam gandrīz aizmirsu to, ar ko vēstule bija jāiesāk: novēlēt laimes Jums kā meitiņas 
tēvam, kuru rītdien kristīs. Es pāris reizes tikos ar Jūsu kundzi pēc dzemdībām: viṇa labi izskatās. Un es jau arī esmu palicis par vecpapi, jo Mežciemam tagad ir dēls. Nu tikai Muceniekam jānāk pie rindas ar saviem pienākumiem pret Latvijas valsti.

Ja Jums būtu iespējams pārbaudīt literatūru par žultsvada ascendējošo infekciju, sevišksi pēc choledochoduodenostomijas, un mums piesūtīt kādu literatūras sarakstu, mēs ar Mežciemu būtu Jums l̦oti pateicīgi. Mums jau ar literatūru vienmēr grūtības.

Tad es Jūs lūgtu orientēties, kā viņi Amerikā rīkojas pie akūtiem ēdamrīkles apdedzinājumiem, t. i., vai viṇi lieto agrīno zondēšanu, kad un kā zondē, kāda amerikāṇu terapija šai lietā? Es gribu sniegt vācu literatūrā mazu pārskatu par mūsu klīnikas nelielo materiālu.

Līdz šim mums ar kuṇga rezekcijām vienmēr gājis ḷoti labi. No kādām 40-50 operācijām - tā es taksēju - mēs esam zaudējuši divus slimniekus, vienu no kādas nervu sistēmas slimības otrā dienā pēc operācijas, jo viņš 24 stundu laikā nomira ar pazīmēm, kas atgādināja delirium tremens (bija alkoholiḳis). Nesen rezecēju vienu kungịi... ar lielu gabalu no colon transversum - repeltato arī bija labi. Mùsu laboratorija vēl nav iekārtota un tagad jau noteikti gaida savu iekārtotāju no Amerikas atbraucam. Līdz tam laikam mums vēl jāpaciešas.

Visā nopietnībā ķeros pie privātklīnikas ierīkošanas un, ja mani asistenti vēlēsies arī vienu otru savu slimnieku tur operēt, tad tas iespējams būs. Tai ziṇā mums liels trūkums un visa latviešu inteligence iet vai nu pie vāciešiem un maksā l̦oti lielu naudu, vai arī Sarkanā Krustā. Man atkal viens slimnieks no Jankovska, kur gastroenterostomijas anastomoze aizaugusi ciet.

Ja Jums atliek laika un Jūs ārstu žurnālam kaut ko piesūtīsat, būtu ḷoti pateicīgi. No 11.-13./IX 1925 mums būs Vislatvijas ārstu kongress ar viesiem no Igaunijas, Lietuvas un varbūt arī Somijas. - L̦oti žēl, ka Jūs neesat mājās, varētu [..]

Jums nekas nebūs pretim, ka es no Jūsu šefrakstnovilkumiem dažus Jūsu vārdā piesūtǐšu dažiem fakultātes locekḷiem.

Fakultātei liels zaudējums: prof. Bakmans iet projām uz Zviedriju. Mēs ne tikai zaudējam labu cilvēku, sirsnīgu kolēgi, krietnu zinātnieku, sirsnīgu pedagogu, bet arī lielu daļu no mūsu fakultātes sirds skaidrības un sirdsapziņas. Man sevišḳi sāp šis zaudējums. Ja mūsu universitātē dažreiz nevaldītu "patrioti" un "nacionālisti", kuru pozitīvais darbs pastāv tikai iekš tam, ka zem nacionālisma maskas ved tādas intrigas un personīgas intereses, visādi apgrūtinādami darbus ārzemes zinātniekiem, kas tiešām ko zina un arī grib un māk strādāt un nepadodas personīgām intrigām, tad mēs Bakmani nebūtu zaudējuši. Uzaicināts Bakmaņa vietā krievs Starkovs (no Kijevas, kurš senāk bijis kiirurgs, daudz strādājis topogrāfiskā anatomijā), kas, kā liekas, arī būs labs mācību spēks.

Jautājums par klīnikas ierīkošanu II pils. slimnīcā gan ierosināts, no Valdības zināma pretimnākšana sasniegta, bet paies vismaz 1 1⁄2 gadi, kamēr mēs tiksim pie savām klīnikām - ja mēs vispārīgi pie tādām tiksim. 


\section{J. Stradinš}

Jūsu kundze lai par savu studiju gaitu neuztraucas, es vismaz viņai nekādus šķēršlus nelikšu! Es dzirdēju, ka viņa gribot braukt pie Jums uz Ameriku. Vai tas būs labi? Vai tas nebūs apgrūtinājums Jums, Jūsu kundzei un mazai meitiņai? Tāds ceḷojums taču nav nieka lieta! Cik tad ilgi viṇa varētu pie Jums būt? Dažus mēnešus tikai. Bet zināms, Jūs jau rīkojaties, kā Jūs paši labāki zināt. Atvainojat, ka es vispārim to ieminējos.

Mana sieva, Mežciems un klīnikas personāls lūdza Jūs sveicināt.

Labas sekmes darbā!

Ar mịlāàm labdienām

Jūsu Alksnis

\section{Rīgā, 14./VII 1925}

Ļoti cien. kolēga kgs!

Saṇēmu šodien Jūsu vēstuli no 12./VII un tūliṇ arī atbildu. Paldies par Jūsu darbu "Latv. Ārstu žurnālam". Tas būs ievietots burtnīcā, kas iznāks augusta beigās. Arī Jūsu vācu valodas darbu esmu jau pārrediǵējis un nodevu Jūsu kundzei pārrakstīt. Tikai diemžēl dažos autoru vārdos darbā un literatūras sarakstā es nevaru katru burtu labi salasīt. Tad arī Jūs citējat vienu savu darbu no Novy vensky archiv, B. 4. H. 21, bet neesat uzdevuši darba nosaukumu un neesat ari to ievietojuši literatūras sarakstā. Ja Jūs tiešām nodomājuši pārbraukt uz 2-3 dienām mājās, tad jau to lietu varētu viegli nokārtot. Ja nē, laikam būtu labāk, ka es Jums to nosūtìtu uz Angliju pārredigèt. Tikko būsiet Anglijā, tūlin man uzdodiet savu adresi. Es Jūsu studiju plānam pilnīgi piekrītu. Praktiskā ķirurğijā Jūs vienmēr paši tālāk iestrādāsities, bet to ne tā laboratorijā. Tamdēl ņemat tagad teorijā, ko vien varat. L,oti labi, ka Jūs apskatīsieties arì Anglijā un varbūt vēl kur. Cilvēks, dabūdams vairāk redzēt, iegūst plašāku redzes loku. L,oti labi, ka Jūs darbus publicējat arī angḷu un krievu valodā, seviški angḷu. Neko nekaiš, ka nodaļas vadītājs līdzi parakstās. Bet vai Jūs tikai nebūtu vienu aizmirsuši - pa daḷai praktiskas dabas lietu: savu disertāciju, lai to varētu tūlin, pēc atbraukšanas publicēt? Par to arī jau padomājat.

Man šķiet, tur nevienam nevarētu būt nekādi iebildumi, ja Jūs pārbrauktu uz pāris dienām Rīgā un būtu arī kongresā. Lielas lietas no kongresa negaidāt, jo kur prof. Zỉle kādu lietu vada, tur tiek putrots bez gala. Oficiālā programma jau apstiprināta un nodrukāta, tur Jūsu darbus vairs nevarētu dabūt iekšā. Mums ķirurǵ̀iskā sekcijā pieteikti kādi 28 darbi. Es esmu sekcijas vadītājs, mani palīgi ir prof. Jankovskis un prof. Mincs. Gan jau mēs vismaz vienu Jūsu priekšlasījumu programmā uzṇemsim - ārpus rindas; ja citādi ne, varbūt kāds no mums ar savu tematu piekāpsies. İsi sakot, gan to lietu nokārtosim. Nezinu, kas fakultātei varētu 
būt par iebildumiem, ja Jūs 2-3 dienas apmeklējat savējos. Tas tikai naudas jautājums. Ar Jūsu komandējumu tā lieta palika tāda, ka konstatēja, ka algu varot maksāt tikai tad, ja esat parastā komandējumā - t. i., ne ilgāk kā 3 mēnešus, pie kam varētu arvien pa 3 mēnešiem pagarināt. Vismaz es jau priekš Jums pieprasīju, lai pagarina komandējumu, bet tagad man škiet, ka neviens tam tomēr vērību nepiegrieza un tagad tā lieta pilnīgi noklusējusi. Es arī nezinu, vai maz vēlreiz pieprasìt. Ja Jūs dabūtu komandējuma pagarinājumu uz kādiem mēnešiem, mēs gan klīnikā izsitīsimies cauri, kā lìdz šim, jo Bormaṇa j-kdze strādā Jūsu vietā un dara to ḷoti labprāt. Mēs citi viṇai piepalīdzam, jo viņa diezgan bailīga un kautrīga. Ja Jums būtu kādas komplikācijas Kara ministrijā, arī tur mēgénāsim Jums piepalīdzēt, ja tas būs vajadzīgs.

Es vienreiz tikos ar Jūsu kundzi. Viṇa drusku vājāka, bet citādi izskatās vesela un spirgta. - Priecājas, ka mazā meitiņa labi augot.

Mēs visi esam veseli. Es līdz šim vēl neesmu bijis atvalinājumā un esmu daudz strādājis. Nosūtīju divus darbus Sauerbrucham, sarakstīis labu pārskatu par fakultātes 5 gadu darbību (Universitātes 5 gadu jubilejai pagājušā gadā) un daudz operēju. Nesen operēju vienu tumor cerebri ([... temporales II et III) ar labām sekmēm. Ulcus materiāls nebeidzas; l̦oti grūti gadījumi. Tātad esmu tā nostrādājies, ka tiešām ilgojos pēc atpūtas, kura man sāksies 1./VIII uz vienu mēnesi.

Paldies par sveicinājumiem. Arī Mežciema dēls aug labi un ir vesels. Visi esam veseli. Arvīds pārbrauca no Francijas un izaudzis lielāks; viņam iet labi.

Mēs visi Jūs sirsnīgi sveicinām

Jùsu Alksnis

\section{J. Alksnis - P. Stradingam}

\section{Rīgā, 12./IX 1925}

\section{Loti cien. kolèga kgs!}

Daudz paldies no manis un manas sievas par apsveicinājumu un laimes novēlējumiem sudraba kāzu dienā. Mēs šo dienu savienojām ar kristībām. Jūsu kundze arī bija mūs pagodinājusi ar apciemojumu. Viṇa izskatās spirgta un vesela.

Jūsu darbs par trofiskiem ulcera jau iespiests ārstu žurnālā. Kad būsiet mājās, Jums iznāksies žurnāla izdevniecībai drusku atlīdzināt par klišejām. Pagaidām rēkins nokārtots.

Patlaban mūsu kongress. Piedalǐšanās lieliska: var rēḳināt kādus 800-900 ārstus un zobārstus, tad vēl studentu apmēram 200. Arī darbu pieteikts ap 100. Jauna gan daudz tie nesniedz, bet tomēr viens otrs ierosinājums ir. Kongresa galvenais punkts: slimokases un profesionālā ārstu savienība. Šĩs lietas pamatīgi iztirzā un 


\section{J. Stradinš̌}

šai ziņā sasniegumi būs laikam vērtīgi. Savienības dibināšana iet ātriem soḷiem uz priekšu. Rìtdien pieṇems rezolūcijas. No mūsu klīnikas uzstājos es, Mežciems, Mucenieks. Plašāk debatēja jautājumu par peritoneja drenēšanu pēc perforatīviem peritonitiem.

Jūsu ziņas par ārstniecisku izglìtību Anglijā ḷoti interesantas. Šo to par to jau zināju, bet Jūsu apgaismojums lietu apgaismo un vēl labāk noskaidro.

Es Jums ieteiktu, Stradina kgs, ja Jums vien tas iespējams, jau tagad sarakstīt savu disertācijas darbu, lai Jūs pēc atbraukšanas to tūlìt varētu aizstāvēt. Tas būtu no svara, lai Jūs ātrāki privātdocentētu un varētu ieņemt Jums piederošu vietu. Tā domāju ne vien es, bet arī citi fakultātes locekḷi.

Uz kongresu atbraucis profesors Talviks no Tērbatas un tas man pasacija, ka Igaunijas kolēgiem komandējums jau pagarināts. Es labprāt gribu pabalstīt Jūsu lūgumu dẹl komandējuma pagarināšanas, tikai iesniedzat. Ja Jūs l̦oti vēlētos vēl veselu gadu, es arī nepretotos, kaut gan man pagrūti iet, jo Bormane, kaut gan jau daudz asistējusi, tomēr vēl diezgan bailīga nelaimes gadỉjumos. Bet vienu pusgadu mēs vēl itin labi varētu bez Jums izsisties cauri. Tā tad nekavējoši iesūtiet fakultātei lūgumrakstu. Ceru, ka Jūsu lūgumu ievēros. Labi, ka Jūs jau esat rakstījuši Budulam. Varbūt rakstiet vēlreiz, ja vajadzīgs, jo no dekāna jau daudz kas atkarājas. Domāju, ka Jums būtu disertācija. Tā man sacija Paukuls. Bet varbūt, ka domas arī jau būs grozījušās.

Es Jūsu rakstu izkoriǵēju un nodevu Jūsu kundzei pārrakstīt. Es Sauerbrucham piesūtīju divus paša darbus, kuri jau uzn̦emti, bet redzu, ka viņš pārāk lielu svaru liek uz izteiksmes un satura īsumu. Vai tikai nebūs Jūsu raksts vēl jāsaīsina? Palasǐšu vēlreiz un padomāšu.

Novēlu Jums veiksmes darbā un veselību. Mana sieva lūdz arī Jums nodot sveicinājumu.

Ar labām dienām

Jūsu Alksnis

\section{J. Alksnis - P. Stradingam}

\section{4./X 1925}

Ļoti cien. Kolēgi!

Man beidzamā laikā bez darbiem arī daudz un dažādu nepatikšanu, jo mūsu puskomunistiskie īres likumi padara neiespējamu privātklīnikas ierīkošanu paša namā, ko es l̦oti vēlējos. Tamdē sūdzības, prāvas ar žīdiem utt., utt. 
Vācu darbu nevarēs tādu nosūtìt, kādu Jūsu kundze to pārrakstījusi: viņai nav bijuši visi vācu burti un viṇa likusi, piemēram,"w"vietā divus "vv". To korektie vācieši nepien̦em. Man šķiet, ka arī pēc satura raksts būs jāsaīsina, jo es iesūtīju nesen divus rakstus "D. Z. f. Ch." un redzu, ka viṇi uz to l̦oti iziet, saīsina pat burtus. Vēl nepaspēju darbu izskatìt otrreiz cauri.

Nosūtu Jums visus "Latv. Ārst. žurn." numurus, kādi līdz šim iznākuši, lai Jūs tos nosūtītu uz Vašingtonu kolonelam Hjume. Sacǐšu arī mūsu galvenās bibliotēkas pārzinim prof. Lejniekam vai prof. Balodim, lai aizsūta Acta Universitatis. Zināms, es ḷoti priecātos, ja mēs saṇemtu no Index Medicus apmaiņas eksemplāru. Par žurnāla virsraksta tulkošanu franču valodā jādabū aț̣auja no Latv. Ārstu biedrības; to mēs ar nākamo gadu ievedīsim.

Gaidīšu no Jums rakstus žurnālam. Tas ir labi, ka Jūs rakstāt savu disertāciju. Tikko pārbrauksiet, tūlin promovēsim un arī pēc dažiem mēnešiem privātdocentēsim. Es uzskatu par nodrošinātu, ka Jūs ieņemsiet kirurğ. proped. klīnikas katedru. Tā arī nodrošināsies Jūsu materiālais stāvoklis. Kad pārbrauksiet, papūlēsimies kaut ko priekš Jums atrast. Es cerēju daudz no privātklīnikas, bet tagad nevaru izdabūt ārā žĩdus no savas mājas. Bet tai vietā patlaban sastādās no latviešu kolēǵiem, kirurgiem un ginekologiem konsorcijs, kas varbūt līdz Jūsu pārnākšanai jau būs ierīkojis plašāku privātklīniku. Dr. Mežciems eksperimentē ar choledochoduodenostomiju un ascendējošo žultscel̦u infekciju. Izoperējis jau 5 suṇus.

Par sava komandējuma pagarināšanu Jūs paši lemjat, kā atrodiet par labu, mēs visi būsim ar mieru ir ar 1 gadu, ir ar 8 mēnešiem. Mès strādājam draudzīgi un savā starpā iztiekam un vēl tālāâk iztiksim. Mēs visi vēlamies, Lai Jūs savu komandējumu izlietojiet tā, kā Jums šḳiet vislabāk. Tātad - izšḳirošs būtu Jūsu materiālais stāvoklis, kā Jūs varētu labāk Rīgā iekārtoties, jo materiālas grūtības kā jaunākam asistentam bez prakses būtu pārāk lielas. Mums nav nekāda nosacīta starpība starp privātdocentēšanu un promovēšanu. Tagad patlaban Dr. Miḳelsons lasa savas privātdocenta proves lekcijas un viņš promovēja vēlāk nekā Mucenieks. Otrs darbs nav vajadzīgs. Bet 2 proves lekcijas fakultātes sēdēs: viena vairāk par paša pētijjumiem, pašizvēlēts temats brīvā valodā, 30 minūtes laika. Pèc tam debates. Otra lekcija: no fakultātes uzdots temats, arī 30 minūtes. Kā redzams, šie nosacījumi jau nav grūti.

Labas dienas Jūsu dūšīgai kundzei, kas uzdrošinājās ar mazu bērniṇu braukt tādu lielu ceḷa gabalu. Cerēsim, ka viṇas abas nonāca Londonā spirgtas un veselas.

Mịlas labdienas no mums visiem un no Mežciemiem!

Jūsu Alksnis

Patlaban nodibinājās Vislatvijas ārstu profesionālā savienība. Galvenais uzdevums: pašpalīdzība (likumi, cinna ar slimokasēm, pašapdrošināšanās nāves gadījumiem), bet arī zinātniskā izglìtība, priekšlasījumi. 


\section{J. Alksnis - P. Stradingam}

\section{8./XI 1925}

\section{L,oti cien. kolēga kgs!}

Beidzamā laikā biju drusku noguris no darbu daudzuma un visādiem saimnieciskiem sarežğỉjumiem, tamdēl arī aizkavējos ar Jūsu darbu un ar atbildi Jums. Bet šodien jau vēlreiz izlasīju Jūsu darbu un nodevi to pārrakstìt. Arī man, šķiet, ka tur vairs nekā nevar saīsināt un darbs ir labs. Pēc pāris dienām tas būs ar mašinu pārrakstīts un es to nosūtīšu tūliṇ Sauerbrucham. Ceru, ka iebildumu nekādu nebūs un darbu pienems.

Man Paukuls ziņoja pavisam negaidītu lietu: Rokfellera fonds fakultātei paziņojis, ka Jums komandējums netikšot pagarināts. Pie tam Fonds sevišķi uzsvēris, ka tā esot principa lieta, ka viņi nemēdzot dot ilgākus par gadu komandējumus, bet pie tam lūdzot fakultāti šo lietu nepārprast un nedomāt, ka Jūs neesot cienīgi pagarinājuma. Gluži otrādi - atsauksmes par Jums esot l̦oti labas. Fonds atrodot, ka Jūs savus pienākumus cienīgi veikuši un viṇi ar Jums esot ḷoti mierā, bet tomēr komandējumu pagarināt nevarot. Bet esot iespējams, ka Jùs vēlāk atkal dabūjat komandējumu uz kādu gadu. Kad es tiku aizdomas izsacijis, vai tikai šeit nav notikusi kāda aizmugures machinācija, kādas intrigas, kamdēḷ tad Prīmanim pagarināšot, bet Jums ne, tad Paukuls man atbildēja, ka mahināciju nekādu neesot, bet tas esot Fonda patstāvīgs lēmums. Par pagarinājumu Prīmanim viņš klusēja, bet aizvakar dzirdēju no Mucenieka, ka Prīmanis arī jau janvāra beigās būšot mājās, jo pats pagarinājuma nevēloties. Cik tur taisnības, nezinu. Varbūt, ka Fonds nelabprāt pagarina klīnicistiem komandējumus, bet teorētiḳiem pagarina. Visādā zin̦ā, es domāju, ka Jūs varbūt arī nemaz tik daudz nezaudējat, ja braucat ātrāk mājās: ātrāk doktorēsiet, ātrāk privātdocentēsiet - un cerēsim, arī ātrāk tiksiet pie savas katedras. Jūsu asistenta vieta Jums paliek, bet tā Jùs nevar materiālā ziṇā nodrošināt. Būs jāiesāk nodarboties arī ar privātpraksi, kamēr dabūsiet proped. klīnikas katedru, un tur mana privātklīnika, kuras liktenis jau nodrošināts, varbūt Jums varēs arī drusku izpalīdzēt. Tik strādīgam un spējīgam, kāds esiet Jūs, arī Dievs palīdzēs. Zināms, Jūsu kundzes un meitiņas celıjums varbūt iznāca drusku nemotivēts un neatmaksājās, bet ko tur darìt?

Labi būtu, ja Jūs savu disertāciju jau būtu uzrakstījuši, mājās pārbraucot. Jūs varētu itin labi izṇemt kādas nodaḷas no Petrogradas disertācijas un tās pārstrādāt par disertāciju, jo tā jau nav publicēta un neviens, izṇemot mani, tās saturu nezina. Prasijumu par 200 eks. drukāšanu iekustināja Paukuls un l̦oti aizstāvēja Buduls. Zināms, principā to noliegt nevar. Mana disertācija savā laikā man izmaksāja kādus 900 rḅ̣. Citiem iznāca lētāk, bet tā ap 400 rḅ̣. izdevumi mēdza svārstīties. Tas tagad būtu 50-100,000 rḅ̣. Bet toreiz algas bija lielākas un dzive lētāka. Cik es varēšu, mēginināšu aizstāvēt jauno doktorandu intereses. Diemžēl 
ārstu žurnāls visu disertāciju nekad nevar nodrukāt, bet varētu jau arī tā iekārtot, ka dažas nodaļas ir patstāvīgi nodrukājamas un tās tad žurnāls varētu ņemt uz sava rēḳina. Varētu to lietu nokārtot arī iekš Acta Universitatis, bet diemžēl šo izdevumu sagrābuši "profesori" savās rokās, ekspluatē to kā ienākumu avotu (saṇem lielākus honorārus), kamdēḷ šim izdevumam mēdz aptrūkt kapitāli. Vai to lietu varēs organizēt, to es nezinu. Tik ātri tā lieta gan neies. Ar 80-100 lpp. disertācijai pietiek.

Paldies par Jūsu referātiem, kuri nāks šinī numurā. Mikrofotogrammas var Rīgā iespiest, iznāk diezgan labas. Par Acta Universitatis nosūtǐsanu Dr. Hume `m vēl nepaspēju runāt, bet šais dienās es to nokārtošu. Mežciems man sacỉja par ordeņa lietu Kolvuelam Reinam un Dr. Hume. Reins tika ievēlēts par universitātes Goda biedru; vai tas sañems arī kādu ordeni, to es nezinu. Vai Dr. Hume kaut ko saņēmis, to es arī nezinu, bet mēgināšu izzināt pie Valsts prezidenta. Jādod viņam kaut kas gan būtu jādod, jo ārzemnieki jau kā bērni uz ordeņiem.

Mežciems, viņa kundze un dēls ir veseli. Strādā pie sava darba par choledochoduodenostomiju, un, kad dabūja zināt, ka Jūs ātrāk būsiet mājās, nekā domājām, liek lielas cerības uz Jums, ka Jūs piepalīdzēsiet veikt biolog̣iski patologisko daļu.

Mēs projektējam atklāt latviešu privātklīniku, lai latviešu ķirurgi nebūtu piespiesti dzīvot no tā, kas no cittautiešu maizes galda nokrīt. Cerams, ka arī Jūs piedalīsaties, pie kam nekādus naudas līdzekḷus vismaz sākumam nevajadzēs. Ja Mucenieks būs ar mieru piedalīties, būs labi, es viṇu arī uzaicināšu. Vēl nezinu, vai viņš to vēlēsies.

Mēs tagad esam tikai 3 personas savā dzīvoklī: sieva, es un mazā Austriṇa. Valda aizbrauca uz Grenobli Francijā studēt franču valodu, vēsturi un literatūru. Tātad rūpju man diezgan, kamēr tādus pienākumus apmierinu. Pašam nodomā pāris darbu, bet nav laika, klāt netieku.

Sirsnīgas labas dienas Jūsu kundzei, Jums un mazai meitai no mums visiem! Jūsu Alksnis

\section{J. Alksnis - P. Stradinam}

\section{Rīgā, 2./I 1926}

L̦oti cien. kolēǵa kgs!

Paldies par Jūsu un Jūsu kundzes apsveicinājumiem jaunā gadā; visi - mazi un lieli - pateicamies. Mums šoreiz svētki iznāca tādi dalīit: Arvīds un Valda Francijā, satikās Grenoblē, kur studē Valda, un Arvīds no Turkoangas turp aizbrauca. Mēs citi, ieskaitot arī Dāvi, Sašu un Mildu, Rīgā, mūsu dzīvoklī. Tomēr... svētki pagāja diezgan mịli savējo starpā, kaut gan es daudz strādāju: nobeidzu pats savu referātu par 172 ulc. ventr. operācijām, kuru iespiežam ārstu žurnālā; tad arī izlaboju un tulkoju Mucenieka disertācijas darbu vācu žurnālam. Bez tam strādāju līdzi un 


\section{J. Stradiň̌}

rediǵēju ārstniecisko daḷu latv. enciklopēdiskā vārdnīcā. Arī "Latv. Ārstu žurnāls" aizṇem laiku. Palīdzu arī Mežciemam pie suṇu operācijām.

Jūsu darbs jau nodrukāts iekš "D. Zeitschrift f. Chir." un patlaban aizsūtu atpakal korektūru. Tātad pēc 1-2 mēnešiem tas jau būs publiski pieietams. Redakcija tikai saīsinājusi dažus vārdus, bet neko nav svītrojusi. Baiḷojos, ka negribēs uzṇemt lielo literatūras sarakstu, bet arī tas uzñemts, tikai tematu virsraksti no centrālžurnālu referātiem un neḳirurgiskiem žurnāliem nosvītroti, bet žurnālu apzīmējumi (nosaukums, gads, sējumi, lpp.) atstāti. Darbu nosaukumi no krievu, angḷu, franču etc literatūras nodrukāti. Tātad tas būtu nodrukāts, gādājiet tikai par nākamo rakstu. Redakcijas durvis mums vaḷā.

Man prof. Paukuls un prof. Buduls sacijja, ka Jūs lūguši komandējuma pagarinājumu uz 2 mēnešiem un vinii tam piekrituši. Tātad viss atkarājas no Fonda, ko tas sacìs. Jocīgi tomēr tā lieta iznāca: no iesākuma Fonda piedāvājums pagarināt itin kā uz gadu, tad noraidījums. Šeit man sacīja, ka Prīmanis nekad neesot gribējis pagarinājumu. Viņš ir cilvēks, kuram pilnīgi uzticēties nevar. Viṇš droši vien vairāk domā par karjeru un naudu, nekā par zinātni. Vai viņš kaut ko nav laidis val̦ām? Vai citu tautu (igauņu, lietuviešu) kandidāti arī nedabūja pagarinājumu? Šie jautājumi mani interesē orientēšanās dēḷ. Es esmu visu darīis, lai Jums piesūtìtu Acta Universitatis un Jūs tos varētu nosūtìt tālāk Dr. Hume. Vēl vakardien runāju ar universitātes bibliotēkas pārzini prof. Lejnieku un viņš solījās tūliṇ, Jums sūtìt. Izdevumus, kas Jums no tam celtos, mēs vēlāk nokārtosim. Tiešo adresi uz Vašingtonu es esmu pazaudējis - bez tam l̦oti ir vēlama Jùsu starpniecība. Prof. Jankovska nāve mums nāca l̦oti negaidīta; viņam tikai 49 gadi. Vai tikai nav bijis lus? Viņš izlikās vesels, kaut gan vienmēr tāds noguris. De mortius nihil nisi bene! Tomēr man jāsaka: mūsu zinātne tur nekā nezaudē. Viņš bija palicis tikai praktikis un karjerists: rauti, konferences ar augstiem kungiem, pozēšana, reklāma; bet no zinātniska un pedagoǵiska darba nebija nekā, pat vairāk - vienaldzība un pat nolaidība. Es no viṇa esmu izbaudījis tādas viltības un pie deguna vazāšanas, kādas nekad agrāk nebiju sagaidījis, kad ar viṇu iepazinos. Un Jums jāzin, ka es viṇam darbības sākumā esmu diezgan daudz pašaizliedzīgi izpalīdzējis. Tagad mums svabadas 2 kirurğ. katedras. Paldies Dievam, kaut gan Dzirne no Liepājas, bijušais krievu lielkṇazu pakalılaizis un liels intrigants, laužas iekšā, tomēr daudz piekritēju viņam nav. Galvenie protežētāji viņam Krimbergs un Sniḳers. Esmu pārliecināts, ka no viṇa kandidatūras nekas neiznāks. Fakultāte jau nolēmusi gaidīt, kamēr Jūs, Mucenieks un Šulcs būsiet privātdocentējuši. Tad izvēlēsies no Jums trijiem. Arī dekāns Buduls tādās domās. Es Jums ieteiktu ar viņu tuvāk iepazìties, resp., lai viņš Jūs labi pazìtu. Viņš ir drusku jocīgs cilvēks, stipri godkārīgs. Tas pie satiksmes un sarakstīšanās Jums būtu jāievēro. Katram cilvēkam jau savas vājības un nav nekas l̦auns, ja tās pēc vajadzības izlieto. Viṇš ir "Ataugas" filistrs un arī Šulcs tur skaitās. Viņš l̦oti protežē Šulcu. Esmu pārliecināts, ka samērā drīzumā pie mums ieņemsiet katedru. Jūs, pēc mana ieskata, esiet pirmais kandidāts. Teorijā Jùs esiet jau gatavs un kas praksē vēl šur tur trūktu, to mēs viegli panāksim. 
Būšu Jums vienmēr izpalīdzīgs, kur vien varēšu. Strādājiet tikai mierīgi. Galvenākais - nobeidziet disertācijas darbu, lai varētu ātrāk promovēt un privātdocentēt. Varbūt līdz tam laikam man izdodas nodibināt kādu privātklīniku, kur mēs visi varētu kopā strādāt un arī savu materiālo stāvokli uzlabot. Vislabāk Jūs gan noderētu ķirurğ. proped. klīnikai ar eksperimentālo patoloǵiju un ķirurğiju.

Paldies Dievam, ka Jūsu meitiña vesela un aug labi. Mūsu gimene ir un paliek dzīvē svarīgs faktors katram cilvēkam, kas tic cilvēcei un progresam. Lai cilvēki tiktu laimīgi, mums vajag izaudzināt veselus un krietnus cilvēkus. Tas nav nekāds šaurs egoisms, tas ir altruisms, tas ir pamats, uz kura uzbūvējas katrs progress.

Mūsu tagadējais valdības sastāvs ir labs. Cerēsim, ka tas ilgāki noturēsies. Man labi paziņas: Ulmanis, Goldmanis, Ziemels un arī citi. Ja Jums būtu kādas komplikācijas ar kara dienestu, tad iesim tieši pie kara ministra Goldmaņa, t. i., ja bez tam nevarēs iztikt. Ja Jums gadītos kaut kādas vajadzības, kuras Sniḳers vai nu nevar, vai negrib nokārtot, tad lūdzu man pie laika rakstiet.

"Latv. Ārstu žurnāla" ārējo izskatu grozīsim tādu, kā Jūs ieteicāt. Es ḷoti ceru uz Jūsu līdzdalību un palīdzību, jo vienam pašam man tomēr iet pagrūti. Netieku pie cita darba. Klīnikā viss pa vecam. Man uzkrāva arī pārraudzību par 21. baraku. Putniņa lietu nevarēja izlabot; tur viņš pats vainīgs. Bormane strādā diezgan čakli, tikai vienmēr kautrīga operēt grūtākas lietas. Mežciems sirds cilvēks un gara dvēsele, čakls un apzinīgs; tomēr varētu būt lielāks progress. Mucenieks - pavisam nostrādājas, paldies Dievam - būšot samazināt savu kasu praksi. Viņam laba operatīva technika, labi piedzīvojumi ar operācijām. Bet teorijā un arī diagnozē - vēl diezgan daudz robu, kas viñam būtu jāpiepilda. Tad arī valodu trūkums sajūtams. Varbūt Jūs viņam uz to aizrādītu? Beidzamā laikā klīnikā atmosfēra ḷoti laba un draudzīga, un tad arī es labi jūtos. Man tādas muļ̣̣ỉbiṇas, kas dažreiz atgadās, iet uz nerviem, un esmu laimīgs, ja viṇu nav.

Par Sark. Krusta priekšnieku ievēlēts pagaidām Dr. Kasparsons. Viņš laikam arī turpmāk paliks.

Novēlu Jums un Jūsu kundzei, kā arī mazai meitai labu izturību pret Londonas miglaino atmosfēru un ceram Jūs pēc pāris mēnešiem visus veselus redzēt Rīgā. Ar labām dienām no manis, manas sievas un Austras.

Jūsu Alksnis

\section{P. Mucenieks - P. Stradiņam}

Mīlo Pāvil! Pēc Tavas otrās vēstules saņemšanas sirdsapziņa mani par daudz sāka mocìt, kādēḷ sēdos tūlìt pie galda un sāku Tev rakstìt. Tu tiešām nel̦aunojies par manu ilgo klusēšanu un nedomā, ka darīju to ar nodomu kāda sevišķa iemesla dēḷ; tu tak zini, ka es vispārīgi esu slinks rakstītājs un darba arī bija gaužām daudz: 


\section{J. Stradiň̌}

pārpildīta baraka, lērums pacientu mājās, disertācija, ǵimenes dzīvei arī kaut cik jāziedo. Pie tam Prīmanim Jackam arī vēl neesu rakstījis, tas jau nu gan zilu vien spḷauj.

Kā jau augšā minēju, ziemā bija ḷoti daudz darba: dažureiz pie 30 operāciju dienā, barakas piebāztas vai līdz jumtam. Pie tam šefs dažureiz operēja arī ārpus mūsu 2 operāciju dienām, kas vēl vairāk traucēja un apgrūtināja darbu. Klīniskais materiāls visu laiku turas tāds pats kā tavā laikā, varbūt kuṇga rezekciju skaits ir palielinājies. Pavasara pusē biežāk dabūjam operēt zarnu samešanās gadijjumus. Bija arī pāris zarnu ruptūras, kuras mani interesē, jo pašlaik rakstu par šiem gadījumiem nelielu darbinu.

Asistentu sapulces pēc tavas aizbraukšanas notika reti, laikam 3-4 reizes. Uzstājamies galvenā kārtā mēs - kirurgi, internisti vienmēr vēl atturīgi. Vienā sapulcē sanācu matos ar šefu par "Nephtalyus haematurica". Strīds bija stingri zinātnisks, par tematu, bet šefam nu gan tas pa prātam nebija. Pa vasaru laikam sēžu nenoturēsim, jo daḷa kollegu ir aizbraukuši atval̦inājumā. Jaunie kolleǵi, kā Luūlaks, abas tavas subasistentes, tāpat arī kollēg̀a Mežciema asistenti strādā dūšìgi. Vienu laiku L̦ūlaks gan bija palicis par daudzi apātisks, bet tagad toties raujas spēcīgi. Attiecības starp klīnikas darbiniekiem varbūt oficiālākas kā agrāk, bet lietišķas un pilnīgi apmierinošas. Citās klīnikās arī status idem. Kol. Rudzìts strādā seviškịi nopietni savā hematoloǵijā un, kā liekas, ar pozitīviem panākumiem. Par to jau nu viņš tev, jādomā, būs rakstījis. Pāris nedēlas atpakal no mūsu augstskolas laikiem uz visiem laikiem [aizbrauca] prof. Bakmans. Pavadijām to sirsnīgi. Viņa vietā ievēlēts prof. Starkovs, kuru ieteicis prof. Ruberts. Pr.-doc. Trofimovs viņu labi pazīstot un slavē stipri: esot viens no labākiem anatomiem, sevišķi apdāvināts, miermìlīgas saticīgas dabas un pie tam apbrīnojams lingvists. Lekcijas lasîšot vācu valodā. Par dekānu ievēelēja vienbalsīgi prof. Buduli, par ko mēs visi priecājamies, jo Buduls laikam ir vienīgais objektīvais, ārpus kliḳēm stāvošs cilvēks no visiem mūsu fakultātes locekḷiem. Šefs arī bija uzstādījis savu kandidatūru, dabūjis tikai 3 balsis, kādēl noskaities un noṇēmis savu kandidatūru uz Universitātes padomes locekli. Par pēdējiem ievēlēti "pretinieki": Krimbergs, Sniķers un Paukuls. Paukuls bez tam arī par jaunu ievēlēts par sekretāru. Vienā no pēdējām fakultātes sēdēm "plaši pazīstamo zinātnes laukā" Dr. Skuju ievēlēja par hospitālās terapeitiskās klīnikas vadītāju: ko tu par to sacīsi? Studenti ir sevišķi uzbudināti par šo fakultātes lēmumu un gatavojas spert nopietnus soḷus. Prof. Ruberts pagājušã semestrī jau lasīja lekcijas, jo bija tik tāļu atspirdzis pēc apopleksijas. Bet vecā Ruberta ir grūti pazīt. Jādomā, ilgu mūžu viņam vairs nedzīvot. Citu sevišķu notikumu mūsu fakultātes un tāpat arī augstskolas dzīvē nav. - Janvāra beigās iesniedzu fakultātei savu disertāciju. Aprīḷa beigās komisija: prof. Paukuls, Jankovskis un mans šefs deva atsauksmes. Tās bija viscaur labas, pat arī Jankovska. Promociju nolika uz 3. V. Bet pa to laiku bija sākuši pūst citi vēji. Jankovskis kādā fakultātes sēdē bija sācis kritizēt manu darbu (tas ir pēc 
labās iepriekšējās recenzijas?), bez tam vajagot darbu papriekšu nodrukāt utt. Tomēr promociju nolika uz 14. V. Tā kā no drošas puses dabūju zināt, ka Jankovskis solījies mani izgāzt, Putniņš ar Skuju arī brukšot virsū, tad garastāvoklis bija nospiedošs. Gatavojos dūšīgi. Kā oficiālie oponenti bija tie paši recenzenti: Paukuls, Jankovskis un mans šefs. Paukuls sākumā slavēja, vēlāk pārmeta manus pārāk optimistiskos uzskatus jautājuma galīgai izskaidrošanai. Tā kā zināju, ka Paukuls pret mani izturējās labvēlīgi, tad ar to arī nekādos garākos strīdos neielaidos. Jankovskis pēc būtības maz ko varēja pārmest: pieḳērās sīkumos, piem., es disertācijā atzīmēju, ka "suṇi nomiruši", tas neesot pareizi, vajagot: "suṇi nobeigušies" utt. Tā kā mantoju iespaidu disputa sākumā, ka Jankovskis vāji pārzina literatūru un manu darbu arī, tikai parakstīies, tad paliku drošs, sāku operēt ar autoriem un statistikām, tā, ka J. vairs neuzbruks un pasacīja, ka šis būšot par to, lai man Dr. med. grādu pieškiirot. Šefs, saprotams, man virsū neuzbruka. Tas sāka pievērsties pie manām tēzēm. Es uzrādīju starp citu tēzes par angīnas zondēšanas nozīmi, par Grekova operāciju, izceldams to kā "Operation d. Wahl" un pēdīgi par "apendikšiem", izskaidrodams to lielo operāciju skaitu ar biežu sievišķo orgānu saslimšanu. Tā kā mani oponenti nemaz nepārzināja attiecīgo literatūru, tad visus uzbrukumus (Jankovska, Putniņa un Skujas) viegli atsitu un mutes aizbāzu ciet. Disputs vilkās vairāk par 3 stundām. Dr. med. grādu piešķīa vienbalsīgi. 22. V kol. Miķ̣elsons arī aizstāvēja savu disertāciju "Par dažām serolog̣iskām tuberkulozes reakcijām". Tā kā darbs bija sevišḳi labs, tad nekāda disputa arī nebija un pēc formalitāšu nokārtošanas Miķelsonam piesprieda attiecīgu grādu. Kol. Šulcs arī beidza savus eksperimentus, rudenī promovēs. Par citiem kolēgiem nekas nav dzirdams. Kol. Mežciemam šefs uzdevis tematu "Par choledochoduodenostomiju" eksperimentēt uz dzīvniekiem. Temats nav pateicīgs. Pēc disertācijas aizstāvēšanas dabūju mēnesi atvaļinājuma. Tā kā uz laukiem neizbraucu un slimniekus mājā pieņemu, operēju arī privātklīnikā, tad arī maz atpūtos un tagad par jaunu strādāju slimnīcā. Savu disertāciju pārtulkoju vācu un krievu valodā. Bez tam gribu uzrakstīt darbu par "volvulu"un turpināšu tālāk savus eksperimentus. Šad tad satiekos ar tavu kdzi, viņa izskatās l̦oti laba. Dūšīga ir arī mana krustmeita: liela dziedātāja. Mani arī var gratulēt ar meitu. - Šefs man lika priekšā uz rudeni iesniegt kādu darbu "pro venia legendi" uz privātdocentūru. Es nu to lietu esmu labi pārdomājis un domāju to darît tikai tad, kad tu būsi pa priekšu sasniedzis šo titulu.

Sirsnīgi sveicinu tevi un, lūdzu, neturi uz manis greizu prātu. Labas dienas no manas sievas.

Tavs Pāvels

Rīgā, 21.VI 25. g.

Prīmaņu Jackam arī nosūtu vēstuli. 


\section{P. Mucenieks - P. Stradiņam}

\section{Rīgā 25. XII 25. g.}

\section{Mìlo Pāvil!}

$\mathrm{Nu}$ jau gan par jaunu pienācis pēdējais laiks tev rakstìt, citādi varbūt atbrauksi ātrāk, nekā savu vēstuli būšu uzrakstīisis un nosūtījis.

Tu jau droši vien zini par prof. Jankovska nāvi; tas mums nāca kā zibens no skaidrām debesīm. Kādu piektdienas vakaru saslima ar apoplexia cerberi un naktī no sestdienas uz svētdienu jau mira. Un tikai nepilnus 49 gadus vecs! Lai nu kādas bija mūsu klīnikas attiecỉbas ar nelaiḳi, tomēr arī mēs ar visiem pārējiem kolēǵiem un plašo sabiedrību dziḷi skumām par pāragro Jankovska nāvi. Bēres bija grandiozas; bez biedrību un dažu iestāžu pārstāvjiem piedalījās arī valdības vīri. Tikai mūsu klīnika gan bija reprezentēta l̦oti vāji: viena Bormaṇa jkdze. Kol. Mežciems operēja ulcus ventriculi perforatio gadījumu, es gulēju slims gultā. Mūsu šefs gan varbūt izturējās drusku demonstratīvi: arī nebija ieradies uz izvadīšanu, ne arī baznīcā. Pat lekciju bija mēginājis lasīt studentiem. Sakarā ar šo apstākli studenti sašutuši. Tagad nu pēc prof. Jankovska nāves izvirzās svarīgs jautājums par hospitālās klīnikas vadītāju. Uzpeld vecie kandidāti: prof. Dzirne, kurš pašlaik ieṇem Liepājas pils. sl. ķirurga vietu, un prof. Mincs. Vairāk tiek daudzināts Dzirnes vārds. No fakultātes locekliem par to ir Krimbergs, Sniķers, Putniņ̌s, Barons, varbūt Paukuls. Zīles stāvoklis nav zināms. Pārējie ar mūsu šefu priekšgalā ir pret Dzirni. Šefs svēti solās karot pret Dzirni ar visiem viņam pieietamiem lïdzekḷiem un izsakās, ka viņš Dzirnem nedos nevienas no savām 4 barakām, ja arī Dzirni ievēelěšot par profesoru, lai viņš apmācot studentus vai uz zvirbuliem! Šefs pāra reizes ar mani runāja par šo lietu un viņam ir cits plāns: lai viens no mums, t. i., Tu vai es - uzņemoties vadīt hospitālo klīniku zem viņa atbildības, kamēr pagaidu vadītājs nebūšot galīgi apstiprināts. Šefs izsakās, ka šo plānu nemaz nebūšot grūti dabūt cauri fakultātei un padomei. Es gan pagaidām (un domāju arī uz priekšu) izturos noraidoši, jo man nav drosmes uzṇemties tik svarīgas klīnikas vadišanu. Katrā ziņā šefs jau savu plānu ievadījis sliedēs un panācis to, ka fakultāte nospriedusi izsludināt konkursu uz hospitālās klīnikas katedru tikai uz nākošo rudeni.

Mūsu klīnikā darbi rit pa vecam. Liekas, ka materiāls ir drusku vienmulīgāks, kā pērnziem. Kung̣u rezekcijas nāk samērā reti priekšā, tāpat arī ekstraoperācijas. Pa vasaru gan bija bieži vispusīgs materiāls: es vien izoperēju kādas 15 kuṇga rezekcijas, 2 smadzeņu audzējus, nieru ekscīzijas, vairākus žultspūšlısus utt. Starp barakām valda pietiekoši laba saskaņa. Kol. L̦ūḷaks laikam samīlējies, tas piegriež mazāk vērỉbas barakai. Bet viņam gan jau sākušies valsts eksāmeni. Kol. Bormane stipri noguruse un palikuse seviš̌ki nervoza, gaida tevi pārbraucam, lai varētu sākt likt doktoreksāmenus. Kol. Borman un Zarin arī dūšīgi liek eksāmenus. Anšmits ir pamatīgi iestrādājies: operē komplicētus volvulis gadījumus ar labiem panākumiem. Kol. Mežciems 
strādā seviškịi nopietni kā klīnikā, tā arī eksperimentējot uz suṇiem. No jauna klīnikā strādā vesela rinda vecāko un 3-4 kursa studentu: kol. Mežciemam ir kādi 4-5, man arī tik pat. Viens otrs no šiem jauniem kolẹgiem ir sevišḳi nopietni, apdāvināti, uzcītīgi, tā ka prieks ar viṇiem kopā strādāt. Šefs ir ḷoti aizṇemts un klīnikai piegriež maz vēribas. Attiecības mums visiem ar vinu labas. Es turpinu savus eksperimentus ar žultsvadu plastiku, bez tam apstrādāju ileus materiālu no 1911. gada sākot. Materiāls ir loti plašs: pāri par 350 gadījumu. Domāju uzrakstīt priekš mūsu žurnāla, bez tam arī saīsinātā veidā vācu un krievu žurnāliem. Savu disertāciju arī pārstrādāju vācu žurnālam un Augstskolas annaḷiem. Krievu valodā nedomāju, jo tas būtu uzkrītoši. Pēc ileus uzrakstišanas apstrādāšu mūsu "Appendix u" materiālu, mēgeināšu noskaidrot vairāk etiologisko pusi. Ceru, ka uz pavasari vai rudeni man būs 12-13 darbu, tad privātdocentēšu. Kol. Šulcs iesniedza savu disertāciju, tā ka pēc gada, jādomā, aizstāvēs. Citi kol. laikam vēl nav uzrakstījuši un Jūs abi ar Prīmani būsat laikam nākošie pēc Šulca. Vesela rinda kolēgu pēc svētkiem sāks likt Dr. med. eksāmenus: Rudzītis, Kaktiņšs, Borman, Mazkalniṇ, Apinis. Eksāmeni jānoliek 2-3 mēnešu laikā. Tu jau laikam zini, ka uz priekšu disertāc. būs jānodrukā 200 eksemplāros un tikai tad pielaidīs aizstāvēt. Kam tas vajadzīgs? Tikai lieki, nevajadzīgi izdevumi. Koleg. Šulcam aț̣āva iesniegt 30 litografētus eksemplārus. Kol. Rudzìtis strādā nopietni savā hematologiijā, tikai tagad darbs jāpārtrauc un jāgatavojas uz eksāmeniem. Viņš sūta tev labas dienas un lūdz apjautāties, vai Anglijā ir fizikālkịmiska medicinas laboratorija, kur varētu strādāt hematolog̣ijā un koloidālā ķīmijā? Viṇš kā Rokfellera fonda kandidāts, jādomā, tiks uz ārzemēm, lai gan viņš nav vienīgais kandidāts no klīnicistiem: arī Fedders ir izbīdìts.

Kol. Miķelsons jau apstiprināts par pr. doc., lai gan gludi negāja. Fakultātes sēdē pēc mèginājuma lekcijas nolasīšanas prof. Zile nikni uzbruka Miḳelsonam, ka pēdējais esot iedomīgs, nemākot izturēties ar cieņu pret augsto sapulci utt. Pēc Ziemassvētkiem Miḳelsons domā lasīt kādu privātkursu rentgenodiagnostikā. Spriežot pēc Zīles izturēšanās, Miķelsons laikam gan tik ātri netiks pie katedras, kas viņam arì nav piedāvāta. - Fakultātes sēdēs vēl vienmēr plēšas ap Putniņa lietu, kurš grib tikt atpakal I Pils. slimnīcā, bet uz to nu gan vinamam nav nekādu cerību. Jautājums par II Pils. sl. nodošanu Augstskolai tālāk par spriedelēšanu netiek, tā ka drīzumā jauno slimnīcu nu gan neatvērs. Prof. Ruberts ir pilnīgi atspirdzis, bet nekādas rosīgas dalības fakultātes dzīvē neņem. Direktors Ziediṇš pēdējā laikā sāk savādāk izturēties, vienu otru reizi rīkodamies tāpat kā bij. direktors Putniņš. Bet ar Ziedin̦u jau nu var iztikt.

Mūsu Rīgas ārstu saime sašķēlusies 2 lēǵeros: mūsu Rigas ārstu prof. b-ba (370 biedru) un kā pretstats tai - Latv. Slimokasu ārstu b-ba (80 biedru) ar stipri kreisu politisku nokrāsu. Ši biedrība strādā ciešā kontaktā ar slimokasu savienību, kādēl, saprotams, ārstu stāvoklis slimokasu darbībā nav nemaz grozījies. Prof. b-ba turpretim viena pati nevar nekā panākt, jo par visām lietām darbība nevar būt progresīva, jo tas nāktu par labu tikai slimokasēm, kuras slimokasu ārstu b-ba aizstāv. Varbūt kaut ko varēs panākt caur jauno Ulmaṇa valdību un tās jauno tau- 
tas labklājỉbas ministru Rubuli. Tu jau nu arī no avīzēm zini, ka šis saimniecỉbas gads sakarā ar pagājušã gada neizdevīgo ražu ir stipri grūts, kādēḷ arī garastāvoklis plašās aprindās ir stipri nospiests. Sevišḳi sūdzas laucinieki un tirgotāji. Pēdējā laikā Rīgā notika vesela rinda solīdu firmu bankrots. Bet lielu apmierinājumu uz Ziemassvētkiem atnesa jaunais Ulmaņa Kabinets, no kura tauta daudz gaida.

Ar savu gimenes dzīvi esu l̦oti apmierināts. Meita aug dūšīgi: šodien jau saskaitijā̄m 5 zobus! Cik manai krustmeitai ir zobu? Savu praksi sašaurinu un domāju uz pavasari pieṇemt tikai 1-2 stundas dienā. Materiāli esu kaut cik nodrošinājies: iepirku Rīgas tuvumā 200 pūrvietu lielu zemnieku māju, tā ka vasaru varēs labi dzīvot. Māja atrodas skaistā vietā uz mazās Juglas krasta verstu 18 no Rīgas. Es tev arī varēšu dot kādu zemesgabalu dzimtīpašumā.

Nu ko dara tava saime? Vai visi veseli? Kad brauksi atpakal, uz Rīgu, lai mēs laikus varam sagatavoties Jūs cienīgi saṇemt. Šefs stāstijja, ka tu būšot marta beigās.

Sirsnīgas labas dienas tev, kdzei un mazajai no manis un sievas, un kolẹgiem. Tavs Pāvels

\section{Saulītis (medicīnas ǵenerāḷa P. Sniķera uzdevumā) - P. Stra- diņam}

\section{Rīgā 6. janvārī 1926. g.}

Mìlo kolēgi!

G̣enerāḷa kungs sirsnīgi pateicas Tev par sniegtām ziṇām un lūdza mani Tev paziņot, ka no viņa puses nav itin nekādu škēeršlı atval̦inājuma pagarināšanai līdz tam laikam, kad Tev izbeigsies stipendijas laiks. Tātad vari mierīgi palikt un strādāt un, kad atbrauksi atpakal uz Latviju, tad visu to formālo pusi nokārtosim. Es vienīgi nezinu, kā Tev ir ar ārzemju pases pagarināšanu. Ja Tev mūsu sūtnis Londonā to nepagarina, tad steidzami man par to atraksti; es parūpēšos tad nokārtot to lietu šeit. Bet ja Tev tās lietas ir kārtībā, tad par kara dienesta lietu Tev nav ko bēdāt - generāḷa kungs ir aț̣āvis pagarinājumu.

Esi tik labs un atsūti, ja iespējams, sekošas sīkākas ziņas par Anglijas armijas sanitāro iekārtu, kuras vajadzīgas mūsu sanitārai pārvaldei:

1) Kara sanitārā pārvaldība (vai priekš armijas un flotes tā ir apvienota jeb vai tās ir atškirtas; vai farmaceitiskā nozare ir tieši padota medicīniskai; vai veterinārā nozare ir padota kara sanitārai pārvaldei; kādi ir kara sanitārās pārvaldes orgāni u. tml.).

2) Sanitārais personāls (par ārstiem jau bija sīkāki iepriekšējā vēstulē), varbūt varētu paziņot kaut ko par kara farmaceitiem un par vidējo un zemāko sanitāro 
personālu (feldšeriem, māsām, sanitāriem vai citiem tamlīdz. amatiem). Kā tiek sagatavots zemākais sanit. personāls?

3) Kādā veidā ir nokārtota sanitārā apgādība armijā (apgādības aparāts, izsniegšanas kārtība karaspēka dạ̦ām).

4) Kara ārstniecības iestādes (viṇu veidi, gultu skaits, speciālās ārstniecības iestādes, kādas ārstniecības iestādes vai punkti pastāv pulkos; ja iespējams, cik liels ir sanitārā personāla sastāvs slimnīcā; uz cik slimniekiem ir viens ārsts, feldšeris, māsa, sanitārs utt.).

5) Vai sanitārais personāls tiek sagatavots palīdzības sniegšanai gāzu (resp., kīmiskā) karā?

Vispārīgi, visas ziņas, kādas vari sadabūt, lūdzu, atsūti mums, jo tas noder pārskatam par citu valstu sanitāro iekārtu un no tā mēs varam arī šo to smelties vajadzīgu priekš mūsu armijas, jo līdz šim priekš acīm ir tikai bij. krievu armijas sanitārās organizācijas paraugs, tad vēl ir arī diezgan bagātīgs materiāls par vācu armiju.

Pie mums nekas seviškss nav no jauna. Bēdīgs gadijums bija prof. Jankovska nāve - viṇu sirsnīgi pavadīja visa universitātes saime un arī plašos apmēros sabiedrība; no karaspēka tika līdzi dota bēru gājienā kareivju godasardze kā bij. Strēlnieku pulku ārstam.

Dr. Prīmanis arī ir šo to atsūtìis no Amerikas un solās vēl atsūtìt vajadzīgo informāciju. Kad atbrauksi uz Latviju, tad no Tevis varēsim saṇemt mutiski plašas ziņas, jo visu tomēr nevar vēstulēs uzrakstìt.

Lūdzu, ja tas Tevi neapgrūtina, atsūtīt kaut nelielu informāciju uz augstāk minētiem jautājumiem, par kuriem gener[ālis] Sniķera kgs vēlas kaut ko tuvāk zināt.

Sirsnīgs sveiciens Tev no generāl̨a kunga.

Ar milı sveicienu

Tavs V. Saulīis

Ja Tev ceḷas kādi sarežğījumi uzturēšanās ziṇā Londonā, tad steidzami atraksti.

\section{Letters adressed to Paul Stradiņš from Latvia in 1925 (Summary)}

\section{By Jānis Stradiņ̌̌}

A correspondence of several leading medical scientists and surgeons from Rīga, Latvia to Dr. med. P. Stradiņš has been published and comented. Dr. P. Stradiņš was one the first Rockfeller fellows (together with J. Primanis) from the young 


\section{J. Stradiņš}

Republic of Latvia (in years 1925-1926) and passed his postdoctoral studies in Mayo Clinics (Rochester, USA) and a Hospital in London, UK. His professors H. Buduls, E. Paukuls, J. Alksnis, P. Snikers from Riga, as well as his collegue in surgery P. Mucenieks informed him regulary about new events in Faculty of Medicine, University in Latvia. These letters give an excellent evidence about problems in medical science in the young university (founded 1919), and are a good source for understanding the situation in Riga. The correspondence has been kept in the private archive of Prof. P. Stradiņš; Dr. J. Stradiņšs, his son, prepared them for publication as early as in 1960, but under the Soviet regime it was not allowed to publish entirely the original text in Latvian. 